\title{
Implementing Environmental Treaty Obligations in Project Finance Activities through an Accountability Mechanism: An Analysis of the World Bank Inspection Panel
}

\author{
Wei-Chung Lin $^{*}$
}

\begin{abstract}
The establishment of the World Bank Inspection Panel is a crucial development in handling the negative social and environmental impacts of Bank-financed projects. It allows affected people to seek redress for the harms resulting from projects, by questioning the legitimacy of the Bank's lending decisions. The Panel has the mandate to examine whether the Bank has complied with its own safeguard policies in specific projects. Even though the substantive rules applicable in the Panel's investigation process (ie, the World Bank's Operational Policies and Bank Procedures) refer to multilateral environmental agreements (MEAs); the Panel has considered the borrowers' environmental treaty commitments extensively in its investigations on a few occasions. This paper examines the extent to which the World Bank Inspection Panel-as an accountability mechanism-has employed different MEAs to address environmental issues resulting from Bank-funded projects, thereby ensuring compliance with environmental treaty obligations in project finance activities.
\end{abstract}

\section{Keywords}

World Bank Inspection Panel, Project Finance Activities, Multilateral Environmental Agreements

\section{Introduction}

In recent years, the World Bank Group has increasingly opened its doors to civil society in order to be more responsive to those who may be affected by its

* Assistant Professor, Macau University of Science and Technology Faculty of Law. Ph.D., LL.M., University of Nottingham; LL.M., LL.B., National Chung Cheng University, Taiwan. E-mail: wei.chung.lin.tw@gmail.com.

The author wishes to thank Professor Mary Footer and Dr. Edward Goodwin for their comments on earlier drafts of this article. The usual caveats apply. 
operations. ${ }^{1}$ The World Bank Inspection Panel (herein, Panel or Inspection Panel) is a classic example of addressing public concerns about the social and environmental impacts of Bank-financed projects. This citizen-driven accountability mechanism allows those who are affected by projects supported by the International Bank for Reconstruction and Development (IBRD) or the International Development Association (IDA) to file claims before it. The Inspection Panel has the mandate to examine whether the Bank's lending decisions have complied with its own safeguard policies.

Legal scholarship has focused on the role of this kind of complaint and grievance mechanism in enhancing the public accountability of multilateral development banks (MDBs). However, a particular strength of the Panel that promotes the implementation of multilateral environmental agreements (MEAs) in project finance has not been explored. This strength relates to the proactive role played by the Inspection Panel in examining the project's compliance with MEA obligations through its investigatory mandate. In the substantive rules applicable in the Inspection Panel's investigation process, MEAs are referred to only on a few occasions. In practice, however, the borrowing governments' MEA obligations have been examined in a manner that is far more extensive than those explicitly stipulated in the Bank's safeguard policies by the Panel. This paper seeks to explore the extent to which the Panel, as a non-judicial mechanism, has employed MEAs to address environmental issues arising from Bank-funded projects, thereby ensuring compliance with environmental treaty obligations in the course of project finance activities.

After this introduction, the second section discusses the institutional aspect of the Inspection Panel. This section initially identifies the Inspection Panel's composition and the rules to safeguard its independence. It then evaluates the accessibility of civil society organisations to the Panel. This involves examining the requirements which an eligible requester and request have to satisfy when making complaints. It also discusses the Panel's investigation process and the procedural reform in recent years. The third section examines the substantive rules applicable in determining environmental issues before the Inspection Panel. It illustrates the World Bank's environment-related safeguard policies, and explores the relationship between, and the cross-fertilisation of, these rules and MEAs. This section also

1 See Sabine Schlemmer-Schulte, 'The Impact of Civil Society on the World Bank, the International Monetary Fund and the World Trade Organization: The Case of the World Bank' (2000) 7 ILSA J Intl \& Comparative L 399. 
considers the influences that these rules may have on different stakeholders. The fourth section analyses how the Panel has treated MEAs in addressing private complaints about environmental impacts arising from Bank-financed projects. Drawing upon the recent practice of the Inspection Panel, this section examines the implications of the Panel's findings for the implementation of MEA obligations in the context of project finance.

\section{The Institutional Aspect of the World Bank Inspection Panel}

\subsection{The Composition of the Inspection Panel}

The Inspection Panel comprises three inspectors of different nationalities. They are nominated by the World Bank's President after consultation with the Bank's Board of Executive Directors ${ }^{2}$ and are appointed by the Board. ${ }^{3}$ Panel members must meet certain criteria, including being able to address the requests thoroughly and fairly, having integrity and independence from Bank Management ${ }^{4}$ and understanding the development issues in, and the living conditions of, developing countries. ${ }^{5}$

To ensure that the Inspection Panel can exercise its investigatory power towards the conduct of the management department in the same institution impartially, safeguarding the Panel's independence is of pressing importance. Five requirements, especially post-employment restrictions, have thus been set out. First, Panel members serve a non-renewable five-year term of office and cannot be re-elected. ${ }^{6}$ Only the Board of Executive Directors can remove them from office. ${ }^{7}$

2 The World Bank's Board of the Executive Directors consists of the Bank's President and 25 Executive Directors. It is responsible for general operations of the Bank and exercises the powers delegated to it by the Boards of Governors under the Articles of Agreement.

The Inspection Panel for the International Bank for Reconstruction and Development, International Development Association: Annex I, Resolution No. 93-10, Resolution IDA No. 93-6 (adopted 22 September 1993) (1995) 34 ILM 520, para 2 [hereinafter 'Resolution Establishing the Inspection Panel'].

The term 'Bank Management' refers to the 'World Bank as an institution involved in the design, appraisal and/or implementation of Bank-financed projects, as distinct from the Board of Executive Directors'. See Operating Procedures of the World Bank Inspection Panel (revised April 2014) 9 <http://ewebapps.worldbank.org/apps/ip/PanelMandateDocuments/2014 Updated Operating Procedures.pdf $>$ accessed 28 July 2016 [hereinafter 'Operating Procedures'].

6 ibid para 3.

$7 \quad$ ibid para 8. 
Second, ex-Bank staff cannot serve as Panel members within two years following the end of their service in the World Bank Group. ${ }^{8}$ Third, Panel members cannot participate in the hearing and investigation of any request in which they have a personal interest or a significant involvement in any capacity. ${ }^{9}$ Fourth, they cannot serve in any other position in the World Bank Group after their service for the Panel. ${ }^{10}$ Fifth, Panel members are considered to be the World Bank's officials when performing their duties, so they enjoy the privileges and immunities granted to Bank officials. ${ }^{11}$

\subsection{The Eligibility Requirements}

According to the Resolution Establishing the Inspection Panel adopted by the IBRD and IDA ${ }^{12}$ and the Clarifications adopted in the first review of the Panel in 1996, ${ }^{13}$ any two or more persons who share some common interests or concerns in the borrower's territory can make a request. ${ }^{14}$ This includes a community of persons, such as an organisation, association, society or other grouping of individuals, or the local representatives of such an affected party. ${ }^{15}$

However, a single individual cannot file a request. The limitation to two or more affected persons to submit a request is due to the concern that if a single individual is allowed to make the request, the Inspection Panel would be flooded

$8 \quad$ ibid para 5.

9 ibid para 6.

10 ibid para 10.

11 ibid; For these privileges and immunities, see Articles of Agreement of the International Bank for Reconstruction and Development (IBRD) (entered into force 27 December 1945) art VIII, sec 8 <http://siteresources.worldbank.org/BODINT/Resources/278027-1215526322295/ IBRDArticlesOfAgreement_English.pdf> accessed 28 July 2016; See also, Articles of Agreement of the International Development Association (IDA) (entered into force 24 September 1960) art VIII, sec 8 <http://siteresources.worldbank.org/BODINT/Resources/278027-1215526322295/ IDAArticlesofAgreementEnglish.pdf $>$ accessed 28 July 2016.

12 Resolution Establishing the Inspection Panel (n 3) para 12.

13 The first review of the Inspection Panel, which resulted in the issuance of the 1996 Clarifications, was required by the Resolution Establishing the Inspection Panel after two years of its establishment. See Resolution Establishing the Inspection Panel (n 3) para 27.

14 Review of the Resolution Establishing the Inspection Panel: Clarification of Certain Aspects of the Resolution (17 October 1996) in David Freestone, The World Bank and Sustainable Development (Martinus Nijhoff 2012) 293-307 [hereinafter '1996 Clarifications'].

Resolution Establishing the Inspection Panel (n 3) para 12. 
with complaints and it would overburden its capacity to investigate. It is also to be expected that the negative impacts of project activities would not only affect a single individual. ${ }^{16}$ When appropriate local representation of such affected parties is not available, the Board of Executive Directors may allow requests from nonlocal representatives. ${ }^{17}$

In contrast, a proposal from Non-Governmental Organisations (NGOs) during the 1996 Review of the Inspection Panel, to the effect that foreign and local NGOs whose rights or interests were not affected by projects should also be allowed to file requests, was rejected. ${ }^{18}$ This reflects the continuing concern that foreign NGOs may use the Inspection Panel to intervene in the domestic affairs of borrowing countries. ${ }^{19}$ The same rationale is also reflected by the fact that there should be a direct link between affected parties and the rights or interests for which they claim to be affected by project activities. In cases where representatives bring requests on behalf of affected parties they should provide evidence that they have been duly entrusted to do so. ${ }^{20}$ Finally, the complaint may also be submitted by entities other than the affected parties. According to the Resolution Establishing the Inspection Panel, in special cases of serious alleged violations of Bank policies and procedures, ${ }^{21}$ any Executive Director may ask the Inspection Panel for an investigation. Also, the Executive Directors acting as a Board may instruct the Panel to conduct an investigation. ${ }^{22}$ However, to date this provision has never been utilised.

Several requirements must be met to initiate the investigation. First, the requester has to demonstrate that its rights or interests have been, or will potentially be, affected by acts or omissions of the Bank. ${ }^{23}$ Second, the alleged damage should result from the Bank's failure to follow its policies and procedures in respect of the project's design, appraisal and/or implementation. Such a failure should also 
have had, or threaten to have, a material adverse effect on the requester. ${ }^{24}$ Third, the requester must demonstrate that the subject matter of the request has been submitted to Bank Management before making the request to the Inspection Panel, and that Bank Management has failed to establish that it has followed, or is taking adequate steps to follow, the Bank's safeguard policies. ${ }^{25}$

\subsection{The Investigation Process}

The Inspection Panel's investigation process has two phases-the eligibility phase and the investigation phase. During the eligibility phase, the Inspection Panel ascertains whether the request is admissible. According to the Operating Procedures, revised April 2014, the Panel will not register a request if: (i) the request is frivolous, absurd or anonymous; (ii) the request does not involve the project which is supported or is being considered for support by the Bank; (iii) the subject matter of the request cannot be plausibly linked to the alleged harm; (iv) the disbursement of the loan is closed or is more than $95 \%$ by the date of receipt of the request; ${ }^{26}(\mathrm{v})$ the matter is related to procurement; or (vi) the subject matter of the request has been dealt with in a prior request, unless there is new evidence or circumstances not known at the time of the prior request. ${ }^{27}$

Regarding the eligibility phase, the Inspection Panel has piloted a new approach with a view to reaching early solutions for issues of alleged harm without recourse to a full investigation. According to the revised Operating Procedures, the Inspection Panel will postpone its decision on registration of the request, which would otherwise be an eligible request, to offer additional opportunities for Bank Management and the requester to address the issues raised in the request. ${ }^{28}$ This optional approach is adopted on a case-by-case basis and depends on the willingness of Bank Management and the consent of the requester. ${ }^{29}$

24 ibid.

25 ibid para 13.

26 For the appropriateness of the cut-off point for filing claims, see Suresh Nanwani, 'Holding Multilateral Development Banks to Account: Gateways and Barriers' (2008) 10 Intl Community L Rev 199, 213-14.

27 Operating Procedures (n 4) para 25.

28 ibid Annex 1, para 2.

29 ibid para 3. 
After the 1999 Review of the Inspection Panel, as will be illustrated below, the Board of Executive Directors' discretionary authority on whether an investigation should be undertaken has to a large extent been shifted to the Inspection Panel. The new pilot approach for early problem-solving through dialogue between different stakeholders further strengthens the Panel's independence from the Board. The adoption of this pilot approach does not affect the Inspection Panel's discretion to recommend a full investigation in light of Management's and the borrower's efforts to address the requester's concerns.

After the registration, Bank Management should submit its response to the request to the Inspection Panel. ${ }^{30}$ Once it has received Management's response, the Panel conducts a preliminary review to determine whether to recommend an investigation to the Board of Executive Directors. In this phase, the Panel assesses whether: (i) there is a plausible causal link between the alleged harm and the project; (ii) the alleged harm and possible non-compliance with Bank policies and procedures are of a serious character; (iii) Bank Management has dealt appropriately with the issues raised in the request, and has clearly shown that it has followed the required safeguard policies, or Management has acknowledged that it did not adhere to relevant policies and procedures; and (iv) remedial actions proposed by Management are adequate. ${ }^{31}$ The Board then makes a final decision. ${ }^{32}$

In addition to the abovementioned requirements, which constitute the basis for the Panel not to recommend the request to the Board for authorising the investigation, in recent years the Panel has also deferred its decision on whether to recommend an investigation in order to provide additional time for Bank Management and the requester to seek solutions. In several cases this has resulted in the Panel not recommending full investigations to the Board. ${ }^{33}$

The Board of Executive Directors used to have considerable discretion in deciding whether to authorise an investigation. In the first five years of the Inspection Panel's operation (ie, from its establishment to the second review of the Inspection Panel in 1999) the Board often turned down the Panel's recommendations. During this period, the Board rejected four out of the six requests recommended by the

33 World Bank Inspection Panel, Accountability at the World Bank: The Inspection Panel at 15 Years (The World Bank 2009) 51-55 <http://ewebapps.worldbank.org/apps/ip/IPPublications/ InspectionPanelAt15yearsEnglish.pdf> accessed 28 July 2016. 
Inspection Panel for investigation. ${ }^{34}$ This happened because, after the Panel's recommendation, but before the Board's decision, Bank Management often agreed on an action plan to address the alleged failure with the borrower and submitted it to the Board. However, such action plans were designed without the involvement of the complainant, other people affected by the project and the Inspection Panel. This practice was also not envisaged by the Resolution Establishing the Inspection Panel or the Inspection Panel's Operating Procedures. This often resulted in the Board's disapproval of the Panel's investigation. ${ }^{35}$

The Board's discretion in authorising the Panel's investigation was restricted following the second review. ${ }^{36}$ According to the 1999 Clarifications, the Board will authorise an investigation without examining the merits of the request. It can only reject the Panel's recommendations for certain technical eligibility reasons. ${ }^{37}$ These requirements are exactly the criteria that the Panel has to satisfy itself in deciding whether to recommend an investigation. This reform not only strengthens the Panel's independence in exercising its investigatory mandate, but also increases the possibility for project-affected people to seek redress through the Panel's investigation. The Board has approved every recommendation since the 1999 Clarifications.

If an investigation is authorised, the Inspection Panel has extensive investigatory powers. Panel members can receive information from various sources. They can interview Bank staff involved with the project concerned and access Bank documents for their investigations. They can also visit the country where the project is conducted after having obtained that country's prior consent. ${ }^{38}$ The Panel can also hold public hearings with the requester during its visits, requesting or

34 These cases are Brazil: Rondônia Natural Resources Management Project, Report on Progress Review of Implementation of Brazil: Rondônia Natural Resources Management Project (25 March 1997); Argentina/Paraguay: Yacyretá Hydroelectric Project, Review of Problems and Assessment of Action Plans (16 September 1997); Brazil: Itaparica Resettlement and Irrigation Project, Report and Recommendation on Request for Inspection (26 June 1997); India: Ecodevelopment Project, Report and Recommendation on Request for Inspection (21 October 1998); For an overview of these cases, see Andria Naudé Fourie, The World Bank Inspection Panel Casebook (Eleven International Publishing 2014) 29-38; 45-52; 61-66; 79-84.

Daniel D Bradlow, 'Private Complainants and International Organizations: A Comparative Study of the Independent Inspection Mechanisms in International Financial Institutions' (2005) 36 Georgetown J Intl L 403, 418-19.

36 For the discussion in the second review of the Inspection Panel, see Shihata (n 16) 173-203.

371999 Clarifications (n 21) para 9.

38 Resolution Establishing the Inspection Panel (n 3) para 21; Operating Procedures (n 4) para 54. 
receiving information from them, or otherwise from project-affected people and others likely to have relevant information. ${ }^{39}$

Upon completion of its investigation, the Inspection Panel submits its findings and conclusions to the Board and the Bank's President, indicating whether Bank policies have been violated. ${ }^{40}$ Bank Management should then submit its report and recommendations (MRR) to the Board, ${ }^{41}$ which includes an action plan devised through consultation with the complainant and agreed between the Bank and the borrower. ${ }^{42}$ The Board then discusses the Panel's findings and Bank Management's MRR, and makes a final decision on the remedial measures to be taken. ${ }^{43}$ It may approve Bank Management's action plan as proposed, or it may require changes or additional measures to address harms. ${ }^{44}$

Finally, regarding the implementation of the action plan that the Board may have approved in response to the findings, the Inspection Panel is not tasked with monitoring how remedial measures are implemented. This has resulted in the filing of new complaints by project-affected people regarding the same project before the Panel. ${ }^{45}$ Now the Board often asks Bank Management to submit progress reports to the Panel and requires the latter to follow up on the implementation of the action plan. $^{46}$

\section{The Applicable Environmental Rules}

The World Bank's operational policies and procedures describe the steps that the Bank's staff should follow during Bank activities to minimise negative social and environmental impacts from Bank-financed projects. These mandatory rules govern the internal activities of the Bank. They become legally binding externally when incorporated into loan agreements between the borrower and the lending institutions. They are also the substantive rules for reviewing the complaints brought by those affected by project finance activities before the Inspection Panel.

40 Resolution Establishing the Inspection Panel (n 3) para 22.

41 Operating Procedures (n 4) para 67.

42 World Bank Inspection Panel (n 33) paras 41-42.

43 Operating Procedures (n 4) para 71.

44 World Bank Inspection Panel (n 33) paras 42-43.

45 Nanwani (n 26) 217-20.

46 World Bank Inspection Panel (n 33) paras 44-45. 
The Bank's safeguard policies are the instruments issued by Bank Management and agreed upon by the Board. The rules were initially adopted as Operational Manual Statements (OMSs) and Operational Policy Notes (OPNs) in the 1970s and 1980s, then converted into Operational Directives (ODs) in 1987. However, since ODs included both binding and non-binding rules, their application caused confusion for Bank staff. To streamline and simplify the practice, Bank Management gradually converted ODs into Operational Policies (OPs) and Bank Procedures (BPs), both of which are mandatory for all Bank staff, and Good Practices, which are non-mandatory. ${ }^{47}$

According to the Resolution Establishing the Inspection Panel, the Bank's safeguard policies include OPs, BPs, ODs and similar documents. ${ }^{48}$ OPs are policy statements that set out the requirements for the Bank's conduct in its operations. ${ }^{49}$ BPs are procedural instructions covering Bank staff requirements for carrying out the policies stipulated in OPs. ${ }^{50}$ ODs have been replaced by OPs and BPs. In the early phases of the Inspection Panel's operation, project-affected people accused the Bank of failure to apply ODs. ${ }^{51}$ These ODs were essentially the current OPs and

47 For a description of the evolution of the Bank's operational policies and procedures, see Shihata (n 16) 41-46.

48 Resolution Establishing the Inspection Panel (n 3) para 12.

49 The World Bank, A Guide to the World Bank: Third Edition (The World Bank 2011) 61 <https://openknowledge.worldbank.org/bitstream/handle/10986/2342/638430PUB0Exto00B ox0361527B0PUBLIC0.pdf?sequence=1\&isAllowed=y $>$ accessed 17 August 2016.

50 ibid

51 See, eg, Nepal: Arun III Hydroelectric Power Project, Request for Inspection (24 October 1994) $<$ http://ewebapps.worldbank.org/apps/ip/PanelCases/1-Request for Inspection (English). pdf $>$ accessed 28 July 2016; India: NTPC Power Generation Project, Request for Inspection (1 May 1997) <http://ewebapps.worldbank.org/apps/ip/PanelCases/10-Request for Inspection (English).pdf> accessed 28 July 2016; China: Western Poverty Reduction Project, Request for Inspection (18 June 1999) <http://ewebapps.worldbank.org/apps/ip/PanelCases/16-Request for Inspection (English).pdf > accessed 28 July 2016; Chad: Petroleum Development and Pipeline Project, Management of the Petroleum Economy Project, and Petroleum Sector Management Capacity Building Project, Request for Inspection (22 March 2001) <http://ewebapps. worldbank.org/apps/ip/PanelCases/22-Request for Inspection (English).pdf > accessed 28 July 2016; India: Coal Sector Mitigation Project and Coal Sector Rehabilitation Project, Request for Inspection (21 June 2001) <http://ewebapps.worldbank.org/apps/ip/PanelCases/23-Request for Inspection (English).pdf> accessed 28 July 2016; Cameroon: Petroleum Development and Pipeline Project (Loan No. 7020-CM) and Petroleum Environment Capacity Enhancement (CAPECE) Project (Credit No. 3372-CM), Request for Inspection (25 September 2002) <http:// ewebapps.worldbank.org/apps/ip/PanelCases/27-Request for Inspection (English).pdf> accessed 28 July 2016; Colombia: Cartagena Water Supply, Sewerage and Environmental Project (Loan No. 4507-CO), Request for Inspection (20 April 2004) <http://ewebapps.worldbank. 
BPs, even though their substantive contents may have been revised. The Panel's jurisdiction is limited to investigating the Bank's compliance with these OPs and BPs.

The Bank's safeguard policies address various environment-related issues that may arise during project activities. ${ }^{52}$ These issues include environmental impact assessment (OP/BP 4.01, ${ }^{53}$ the term 'environmental assessment' is used in Bank policies and procedures), 'Environmental Action Plans' (OP/BP 4.02), ${ }^{54}$ Natural Habitats' (OP/BP 4.04), 'Pest Management' (OP 4.09) ${ }^{56}$ and 'Forests' (OP/BP 4.36). ${ }^{57}$ The Bank should incorporate these requirements into its loan agreements

org/apps/ip/PanelCases/31-Request for Inspection (English).pdf> accessed 28 July 2016; Pakistan: National Drainage Program Project (Credit No. 2999-PAK), Request for Inspection (10 September 2004) <http://ewebapps.worldbank.org/apps/ip/PanelCases/34-Request for Inspection (English).pdf > accessed 28 July 2016.

52 It has been contended that the Bank's safeguard policies have in many ways reflected international environmental law as stipulated in the Rio Declaration on Environment and Development (adopted 14 June 1992) (1992) 31 ILM 874. Charles E Di Leva, 'International Environmental Law, the World Bank, and International Financial Institutions' in Daniel D Bradlow, David B Hunter (eds), International Financial Institutions and International Law (Kluwer Law International 2010) 352-63.

53 See The World Bank, Environmental Assessment (January 1999) OP $4.01<$ https://policies. worldbank.org/sites/ppf3/PPFDocuments/Forms/DispPage.aspx?docid=1565\&ver=current $>$ accessed 28 July 2016; The World Bank, Environmental Assessment (January 1999) BP 4.01 <https://policies.worldbank.org/sites/ppf3/PPFDocuments/Forms/DispPage.aspx?doc id=1578\&ver=current $>$ accessed 28 July 2016.

54 See The World Bank, Environmental Action Plans (July 2015) OP $4.02<$ https://policies. worldbank.org/sites/ppf3/PPFDocuments/Forms/DispPage.aspx?docid=3528\&ver=current $>$ accessed 28 July 2016; The World Bank, Environmental Action Plans (July 2015) BP $4.02<$ https:// policies.worldbank.org/sites/ppf3/PPFDocuments/Forms/DispPage.aspx?docid=3529 \&ver=current $>$ accessed 28 July 2016.

55 See The World Bank, Natural Habitats (April 2013) OP $4.04<$ https://policies.worldbank.org/ sites/ppf3/PPFDocuments/Forms/DispPage.aspx?docid=1567\&ver=current $>$ accessed 28 July 2016; The World Bank, Natural Habitats (April 2013) BP $4.04<$ https://policies.worldbank.org/ sites/ppf3/PPFDocuments/Forms/DispPage.aspx?docid=1581\&ver=current $>$ accessed 28 July 2016.

56 See The World Bank, Pest Management (August 2004) OP $4.09<$ https://policies.worldbank. org/sites/ppf3/PPFDocuments/Forms/DispPage.aspx?docid=1637\&ver=current $>$ accessed 28 July 2016.

57 See The World Bank, Forests (April 2013) OP $4.36<$ https://policies.worldbank.org/sites/ppf3/ PPFDocuments/Forms/DispPage.aspx?docid=1574\&ver=current $>$ accessed 28 July 2016; The World Bank, Forests (April 2013) BP $4.36<$ https://policies.worldbank.org/sites/ppf3/ PPFDocuments/Forms/DispPage.aspx?docid=1585\&ver=current $>$ accessed 28 July 2016. 
with the borrower in binding terms and supervise the borrower's implementation of its contractual obligations. ${ }^{58}$

There are several aspects to the relationship between the Bank's environmentrelated safeguard policies and international environmental law. First, the interpretation of these Bank rules may have to take into account principles and rules of international law, which could extend to environmental norms. ${ }^{59}$ This is especially so when Bank rules explicitly refer to a specific MEA, ${ }^{60}$ international environmental treaties and agreements ${ }^{61}$ or 'applicable international environmental agreements. ${ }^{62}$ These Bank rules (such as OP 4.11, OP/BP 4.01 and OP 4.36) may contribute to the fulfilment of relevant MEA obligations during project activities. ${ }^{63}$

Second, certain Bank policies require the borrower's national legislation to be adhered to in Bank-financed projects. ${ }^{64}$ Consequently, international commitments that the borrower has undertaken and incorporated into the host country's national legislation would constitute the borrower's obligations throughout all project activities. Bank staff should be aware of the borrower's international undertakings and take them into account during the project's design, appraisal and implementation. ${ }^{65}$ This is important because borrowing states' environmental commitments in other international fora may become their substantive obligations via the Bank's safeguard policies. paras 1 and 12(c).

59 Daniel D Bradlow, 'International Organizations and Private Complainants: The Case of the World Bank Inspection Panel’ (1994) 34 Virginia J Intl L 553, 608-09.

60 See The World Bank, Physical Cultural Resources (June 2006) OP 4.11, para $3<$ https://policies. worldbank.org/sites/ppf3/PPFDocuments/Forms/DispPage.aspx?docid=1571\&ver=current $>$ accessed 28 July 2016.

61 See The World Bank, Environmental Assessment (January 1999) OP 4.01, para $3<$ https://policies. worldbank.org/sites/ppf3/PPFDocuments/Forms/DispPage.aspx?docid=1565\&ver=current $>$ accessed 28 July 2016; The World Bank, Environmental Assessment (January 1999) BP 4.01, paras 10 and 19 <https://policies.worldbank.org/sites/ppf3/PPFDocuments/Forms/DispPage. aspx? docid $=1578 \& v e r=$ current $>$ accessed 28 July 2016.

62 See The World Bank, Forests (April 2013) OP 4.36, para $6<$ https://policies.worldbank.org/ sites/ppf3/PPFDocuments/Forms/DispPage.aspx?docid=1574\&ver=current $>$ accessed 28 July 2016.

63 Laurence Boisson de Chazournes, 'Policy Guidance and Compliance: The World Bank Operational Standards' in Dinah Shelton (ed), Commitment and Compliance: The Role of NonBinding Norms in the International Legal System (OUP 2000) 297.

64 See OP 4.01, Environmental Assessment (n 53) para 3; OP 4.11, Physical Cultural Resources (n 60) para 3.

65 See Operating Procedures (n 4) paras 1 and 12(c). 
Although the Bank's safeguard policies are its internal regulations aiming at binding Bank staff in handling project activities, their application can have farreaching implications for the Bank, the borrowing government and civil society. ${ }^{66} \mathrm{In}$ terms of the Bank, since its staff must comply with these standards, their decisions on relevant social and environmental issues constitute the Bank's important practice on project finance operations. Also, by requiring the borrower to meet the requirements of the loan agreement, especially to refrain from contravening its environmental treaty obligations, the Bank plays a crucial role in promoting compliance with MEAs. ${ }^{67}$

In terms of the borrower, while the Bank's safeguard policies are not intended to impose obligations directly on the borrowing government when receiving Bank finance, the borrower has to carry out substantive obligations throughout the project cycle when these rules are incorporated into the loan agreement. If the borrower fails to meet its contractual obligations, the Bank can impose sanctions (such as suspension or cancellation of the loan) on the borrower. ${ }^{68}$ This shows the profound impact that the Bank's safeguard policies can have on the manner in which the borrower conducts its project finance activities.

The external effects of the Bank's safeguard policies are also evident with civil society. As these standards aim to ensure the quality of the Bank's project finance operations, they are not formulated in terms of individuals' rights. ${ }^{69}$ Nevertheless, when these rules are duly implemented, they can protect the rights or interests of local populations in borrowing countries. Project-affected people can use these rules to question the legitimacy of the Bank's lending operations. The Bank's safeguard policies thus constitute an avenue for civil society to oversee the lending institution's activities. Through the Panel's investigation and the Board's remedial measures when non-compliance is found, civil society may seek to protect its welfare through these instruments. Meanwhile, by airing grievances and making arguments through the Panel, civil society may influence the interpretation of Bank policies and the Bank's future operations on project finance.

Laurence Boisson de Chazournes (n 63) 191-92. Ibrahim F I Shihata, The World Bank in a Changing World, vol 3 (Brill 2000) 514-16. Ibrahim F I Shihata, 'Implementation, Enforcement, and Compliance with International Environmental Agreements - Practical Suggestions in Light of the World Bank's Experience' (1996) 9 Georgetown Intl Environmental L Rev 37, 49-51.

See Donald K Anton and Dinah L Shelton, Environmental Protection and Human Rights (CUP 2011) 808 . 
As far as Bank policies are concerned, there may be cross-fertilisation between these social and environmental standards and international law. ${ }^{70}$ First, while these rules are not legally binding under international law, it has been argued that through their incorporation into the loan agreement and their constant practice by borrowing countries in their domestic legislation as well as by MDBs in their lending decisions, the substantive contents of these rules may acquire customary status under international law. ${ }^{71}$ Second, the Panel may refer to principles and rules of international law when interpreting these social and environmental rules. ${ }^{72}$ More importantly, by promoting the integration of international practice into Bank policies, via private complaints submitted to the Inspection Panel, civil society may contribute to the development of the substantive contents of these rules and their implementation in project finance activities.

\section{The Practice of the World Bank Inspection Panel}

The Inspection Panel's first ever investigation was Nepal: Arun III Hydroelectric Power Project in 1994. Since then, until 2014, the Board of Executive Directors has authorised 31 investigations and the Inspection Panel has completed all of these. ${ }^{73}$ Almost all of these investigations involve multiple claims in the same case

70 Laurence Boisson de Chazournes (n 63) 297-301; For the discussion of the influences of the Bank's operational standards, see David Freestone, 'The Environmental and Social Safeguard Policies of the World Bank and the Evolving Role of the Inspection Panel' in Alexandre Kiss, Dinah Shelton and Kanami Ishibashi (eds), Economic Globalization and Compliance with International Environmental Agreements (Kluwer Law International 2003) 144-45; Benedict Kingsbury, 'Operational Policies of International Institutions as Part of the Law-Making Process: The World Bank and Indigenous Peoples' in Guy S Goodwin-Gill and Stefan Talmon (eds), The Reality of International Law: Essays in Honour of Ian Brownlie (OUP 1999) 338-42.

71 David Freestone (n 70) 191-92.

72 See Daniel D Bradlow and Sabine Schlemmer-Schulte, 'The World Bank's New Inspection Panel: A Constructive Step in the Transformation of the International Legal Order' (1994) 54 Zeitschrift für ausländisches öffentliches Recht und Völkerrecht 392, 404-05.

73 This excludes Argentina/Paraguay: Yacyretá Hydroelectric Project (1996), where the Board, while refusing to approve a full investigation, authorised the Inspection Panel to conduct a review of the existing problems of the project and assessed the adequacy of the action plan as agreed between Management and the two borrowing countries to address the problems. The Inspection Panel, Argentina/Paraguay: Yacyretá Hydroelectric Project, Review of Problems and Assessment of Action Plans (16 September 1997) <http://ewebapps.worldbank.org/apps/ip/ PanelCases/7-Review and Assessment (English).pdf> accessed 28 July 2016. 
and alleged violations of the Bank policy on EIA. ${ }^{74}$ Other important environmental issues the Panel has addressed include natural habitats and forests. Using several disputes as case studies, this section examines the extent to which the Inspection Panel has effectively promoted the fulfilment of environmental treaty obligations in project finance activities when addressing environmental issues brought by project-affected people.

\subsection{Environmental Impact Assessment (EIA)}

To ensure that Bank-financed projects are environmentally sound and sustainable, Bank policies require an EIA to be conducted in the project. ${ }^{75}$ An EIA identifies a project's potential environmental impacts, examines alternatives and offers options for improving project implementation. ${ }^{76}$ The issues that an EIA should consider include natural environment, human health and safety, social aspects, ${ }^{77}$

74 There are certain exceptions in this regard. See, eg, The Inspection Panel, Albania: Integrated Coastal Zone Management and Clean-Up Project (IDA Credit No. 4083-ALB), Investigation Report (24 November 2008) <http://ewebapps.worldbank.org/apps/ip/PanelCases/47Investigation Report (English).pdf> accessed 28 July 2016; The Inspection Panel, Panama: Land Administration Project (Loan No. 7045-PAN), Investigation Report (16 September 2010) $<$ http://ewebapps.worldbank.org/apps/ip/PanelCases/53-Investigation Report (English).pdf> accessed 28 July 2016; The Inspection Panel, Cambodia: Land Management and Administration Project (Credit No. 3650-KH), Investigation Report (23 November 2010) <http://ewebapps. worldbank.org/apps/ip/PanelCases/60-Investigation Report (English).pdf $>$ accessed 28 July 2016; The Inspection Panel, Kenya: Natural Resource Management Project, Investigation Report (22 May 2014) <http://ewebapps.worldbank.org/apps/ip/PanelCases/84 - Investigation Report (English).pdf > accessed 6 December 2016. OP 4.01, Environmental Assessment (n 53) para 1.

76 ibid para 2.

77 Social aspects include involuntary resettlement, indigenous peoples and physical cultural resources. There are other Bank policies addressing these issues: see The World Bank, Indigenous Peoples (July 2005) OP 4.10 <https://policies.worldbank.org/sites/ppf3/PPFDocuments/ Forms/DispPage.aspx?docid $=1570 \&$ ver $=$ current $>$ accessed 28 July 2016; The World Bank, Indigenous Peoples (July 2005) BP $4.10<$ https://policies.worldbank.org/sites/ppf3/ PPFDocuments/Forms/DispPage.aspx?docid=1582\&ver=current $>$ accessed 28 July 2016; Physical Cultural Resources, OP/BP 4.11 (n 60); The World Bank, Involuntary Resettlement (December 2001) OP 4.12 <https://policies.worldbank.org/sites/ppf3/PPFDocuments/ Forms/DispPage.aspx?docid=1572\&ver=current $>$ accessed 28 July 2016; The World Bank, Involuntary Resettlement (December 2001) BP 4.12 <https://policies.worldbank.org/sites/ppf3/ PPFDocuments/Forms/DispPage.aspx?docid=1584\&ver=current $>$ accessed 28 July 2016. 
and transboundary and global environmental aspects. ${ }^{78}$ The country's institutional capacities in dealing with EIA-related issues, ${ }^{79}$ its domestic policy framework and legislation, and its obligations regarding project activities under international environmental agreements must also be considered. ${ }^{80}$

The borrower has an obligation to conduct an EIA, ${ }^{81}$ though the Bank advises on its EIA requirements and reviews the findings and recommendations of the EIA to determine if it provides an adequate basis for processing the project for Bank financing. When the borrower has completed or partially completed EIA work prior to the Bank's involvement in a project, the Bank also reviews the EIA to ensure that it is consistent with this policy. It may require additional EIA work to be done by the borrower. ${ }^{82}$

When undertaking an EIA in a proposed project, the first step is environmental screening, ie to decide the appropriate extent and type of analysis to adopt. According to OP 4.01 as revised in 2013, a project should be classified as Category A when it is likely to have 'significant adverse environmental impacts that are sensitive, diverse, or unprecedented. ${ }^{83}$ The impact is considered sensitive when it involves issues covered by other Bank policies, such as natural habitats, indigenous peoples, physical cultural resources or involuntary resettlement.

An EIA for a Category A project should examine the project's potential environmental impacts and compare them with those of feasible alternatives. It should also recommend any measures to prevent, minimise, mitigate or compensate for such impacts and improve environmental performance. ${ }^{84}$ Moreover, the borrower should retain independent experts not affiliated with the project to undertake the EIA. ${ }^{85}$ An advisory panel, which comprises independent and internationally recognised environmental specialists, should be appointed to advise on all aspects of the project relevant to the EIA if the project is 'highly risky or contentious or (...) involves serious and multidimensional environmental concerns. ${ }^{86}$

80 ibid para 3.

81 ibid para 4.

82 ibid para 5.

83 ibid para 8(a).

84 ibid.

85 ibid para 4.

86 ibid. 
An EIA report for a Category A project has to include an executive summary; a policy, legal and administrative framework; a project description; the baseline data; environmental impacts; an analysis of alternatives; and an environmental management plan. ${ }^{87}$ There are other issues that also have to be addressed, including a potential regional/sectoral EIA $^{88}$ and the institutional capacity of the borrower. ${ }^{89}$

Among other things, an EIA has to examine a project's environmental impacts. The aspects of environmental impacts that should be evaluated for a Category $A$ project include: (i) the project's likely positive and negative impacts; (ii) mitigation measures and any residual impacts that cannot be mitigated; (iii) opportunities for environmental enhancement; and (iv) the extent and quality of available data, key data gaps, and uncertainties associated with those predictions. ${ }^{90}$

\subsubsection{DR Congo: Forest-related Operations Project}

An inadequate analysis of impacts from the project on the borrower's environmental treaty obligations became a contentious issue in Democratic Republic of Congo: Transitional Support for Economic Recovery Grant (TESRO) and Emergency Economic and Social Reunification Support Project (EESRSP) (the 'DR Congo: Forest-related Operations Project').

The dispute involved two inter-related activities. EESRSP included five components to assist the borrowing government's economic reforms. The complaint mainly focused on its institutional element, which included the preparation of a forest zoning plan and the implementation of the new forest concession system. ${ }^{91}$

OP 4.01, Environmental Assessment, Annex B (Content of an Environmental Assessment Report for a Category A Project) para 2; Each of these items has more detailed stipulations in respective Bank policies. See, eg, Annex B, para 2(c) (Project Description); para 2(d) (Baseline Data); para 2(e) (Environmental Impacts); para 2(f) (Analysis of Alternatives) $<$ https://policies. worldbank.org/sites/ppf3/PPFDocuments/Forms/DispPage.aspx?docid=3902\&ver=current $>$ accessed 17 August 2016. ibid para 7, Annex A, paras 7, 9 <https://policies.worldbank.org/sites/ppf3/PPFDocuments/ Forms/DispPage.aspx?docid=3901\&ver=current $>$ accessed 17 August 2016. ibid para 13.

90 ibid Annex B, para 2(e).

91 The Inspection Panel, Democratic Republic of Congo: Transitional Support for Economic Recovery Grant (TSERO) (IDA Grant No. H 1920-DRC) and Emergency Economic and Social Reunification Support Project (EESRSP) (Credit No. 3824-DRC and Grant No. H 064-DRC), Investigation Report (31 August 2007) paras 15-22 <http://ewebapps.worldbank.org/apps/ip/ PanelCases/37-Investigation Report (English).pdf > accessed 28 July 2016. 
Moreover, TESRO was a budget support operation that supported, inter alia, an improvement of governance in the natural resources sector. The forest-related prior actions that had to be met before the Board approved its operation were a legal review of forest concessions and an extension of the moratorium on new logging concessions. $^{92}$

The complaint was brought by indigenous Pygmy organisations and Pygmy support organisations in the DR Congo on their own behalf and on behalf of affected communities. The complainants argued that the forest sector reform activities that the project supported had harmed, and would continue to harm, the forests where these indigenous peoples lived and on which they relied for their livelihood. They contended that the significant adverse social and environmental impacts that may result from the reform programme were one reason why the project should have been assigned a Category A status and an extensive EIA should have been conducted. ${ }^{93}$

In this case, the Panel not only held that the project had failed to undertake an EIA on the pilot forest zoning ${ }^{94}$ and the logging concession review process, ${ }^{95}$ it also considered the borrower's MEA obligations concerning project activities, although the complainants did not raise this. The Panel held that the DR Congo had obligations under the Convention Concerning the Protection of the World Cultural and Natural Heritage $(\mathrm{WHC})^{96}$ and the Convention on International Trade in Endangered Species of Wild Fauna and Flora (CITES); ${ }^{97}$ both to which the DR Congo was a party. ${ }^{98}$

As for the WHC, the Panel found that one of the borrower's natural sites (Salonga National Park), which was included in the List of World Heritage in Danger, appeared to be adjacent to two areas held by concessions. ${ }^{99}$ As for the CITES, the Panel noted that there were high-value species of timber in the borrower's territory. In particular, one of the species, ie the African Teak (Pericopsis elata), was listed

92 ibid paras 31-36.

93 ibid, Request for Inspection (30 October 2005) 7-8.

94 DR Congo Forest-Related Operations, Investigation Report (n 91) paras 343-46.

95 ibid paras 349-50.

96 Convention Concerning the Protection of the World Cultural and Natural Heritage (adopted 16 November 1972, entered into force 17 December 1975) 1037 UNTS 151 [hereinafter 'WHC'].

97 Convention on International Trade in Endangered Species of Wild Fauna and Flora (adopted 3 March 1973, entered into force 1 July 1975) 993 UNTS 243 [hereinafter 'CITES’].

98 DR Congo Forest-Related Operations, Investigation Report (n 91) para 387.

99 ibid paras 388-90. 
under CITES Appendix II and had been subject to export control. ${ }^{100}$ The Panel stated that if the project's EIA had been conducted in accordance with Bank policy, it should have identified these international obligations and evaluated the project's implications for the pertinent World Heritage Sites and CITES-listed species. ${ }^{101}$

This was the first time that the Inspection Panel addressed the issue of environmental impact analysis in terms of the borrower's MEA obligations. As for the WHC, for a natural site to be included in the World Heritage List (WHL), it should be of outstanding universal value. ${ }^{102}$ According to the WHC, States Parties have to take effective and active measures for the protection, conservation and presentation of cultural and natural properties in their territories. ${ }^{103}$ Also, for the properties included in the List of World Heritage in Danger, major operations are necessary for their conservation, and assistance has been requested under the WHC to protect such sites. ${ }^{104}$ As of 2015, the List of World Heritage in Danger has 48 properties, five of which-all natural sites-are in the DR Congo. ${ }^{105}$ Although the concession areas in this case were not on the WHL, they were in close proximity to a World Heritage Site. The Inspection Panel thus held that implications for the Site should have been evaluated.

Regarding the CITES, the purpose of the Convention is to protect wildlife listed in its three Appendices through international trade controls. ${ }^{106}$ Among other things, Appendix II species are not necessarily threatened with extinction, but they may become so unless trade is controlled. ${ }^{107}$ The export of Appendix II species is prohibited unless an export permit is granted under the authorisation of the state of export. ${ }^{108}$ The species concerned in this case, ie the African Teak, had been subject to export control at that time. ${ }^{109}$ Considering the high economic value of

100 ibid paras 391-93.

101 ibid para 394.

102 WHC (n 96) art 2; United Nations Educational, Scientific and Cultural Organisation, 'Operational Guidelines for the Implementation of the World Heritage Convention' (revised July 2013) WHC 13/01, paras 77-95 <http://whc.unesco.org/archive/opguide13-en.pdf> accessed 28 July 2016; For an analysis of the criteria, see Michael Bowman, Peter Davies and Catherine Redgwell, Lyster's International Wildlife Law (2nd edn, CUP 2011) 464-70.

103 WHC (n 96) art 5.

104 ibid art 11(4).

105 The information is available at UNESCO, 'List of World Heritage in Danger' <http://whc. unesco.org/pg.cfm?cid=86> accessed 28 July 2016.

106 CITES (n 97) Preamble.

107 ibid art II(2).

108 ibid art IV(2).

109 DR Congo Forest-Related Operations, Investigation Report (n 91) para 393. 
the African Teak as timber assets, the Inspection Panel also held that the impacts of concessions should have been evaluated.

The Inspection Panel's explicit references to the WHC and CITES without the complainants raising them shows how it played an even more active role than the complainants in asserting the borrower's MEA obligations when undertaking the EIA. What is more important is that the Panel has indirectly imposed additional treaty requirements on the Bank, which was not a signatory to either of these MEAs and was not bound by them in a strict sense, in being required to consider the borrower's environmental treaty commitments when deciding to finance projects.

\subsubsection{Albania: Power Sector Generation and Restructuring Project}

The involvement of project-affected populations and local NGOs in the EIA process is important for the public to better understand the implications of proposed project finance activities. Public consultation with those affected can help to identify, not only potential impacts of projects, but also solutions for such impacts. ${ }^{110}$

Disclosure of information by the borrower is the prerequisite for public consultation in the EIA. Without knowing about projects and acquiring adequate information about them, affected people cannot meaningfully participate in the EIA process. Therefore, the Bank policy on EIA calls for the borrower to provide relevant project documentation in a timely manner prior to consultation. The information should be in a form and language that is understandable and accessible for those consulted. ${ }^{111}$ For Category A projects, in particular, a summary of the project's objectives, descriptions and its potential impacts should be provided for the initial consultation. A summary of the EIA's conclusions should also be provided once the draft EIA has been prepared. Finally, the borrower should make the draft EIA report available in an accessible place for project-affected people. ${ }^{112}$

In addition to information disclosure, the borrower has to consult projectaffected people and local NGOs about the environmental aspects of the project and incorporate their opinions. Public consultation should be held as early as

110 The Inspection Panel, Cambodia: Forest Concession Management and Control Pilot Project (Credit No. 3365-KH and Trust Fund. 26419-JPN), Investigation Report (30 March 2006) para $255<$ http://ewebapps.worldbank.org/apps/ip/PanelCases/36-Investigation Report (English). pdf $>$ accessed 28 July 2016.

111 OP 4.01, Environmental Assessment (n 53) para 15.

112 ibid para 16. 
possible. ${ }^{113}$ For Category A projects, in particular, consultations must be conducted at least twice: (i) shortly after environmental screening and before the terms of reference for the EIA have been finalised; and (ii) once a draft EIA report has been prepared. Consultations should be held throughout the project's implementation as is necessary to tackle EIA-related issues affecting such groups. ${ }^{114}$

The delay in holding public consultations during project preparation and implementation has become a contentious issue in several cases. ${ }^{115}$ Albania: Power Sector Generation and Restructuring Project is the one that deserves discussion because, in finding the borrower's non-compliance, the Inspection Panel considered the former's treaty obligations which had also been referred to in the complaint. The project involved the construction of a thermal power station (Vlora Thermal Plant) in the Vlora area. The Civic Alliance for the Protection of the Bay of Vlora submitted the complaint on behalf of local residents. ${ }^{116}$

The complainants maintained, amongst others, that there were no adequate public consultations during project preparation. They argued that most public meetings were not properly announced, and that the information provided before the meetings was incomplete. Moreover, the meetings were held only after the location of the power plant had been decided. ${ }^{117}$ The complainants further stated that a communication regarding the borrowing government's non-compliance with its obligations on public participation and access to information had been

113 ibid para 14.

114 ibid.

115 See, eg, The Inspection Panel, Colombia: Cartagena Water Supply, Sewerage and Environmental Project (Loan No. 4507-CO), Investigation Report (4 June 2005) paras 236-42 <http://ewebapps.worldbank.org/apps/ip/PanelCases/31-Investigation Report (English).pdf> accessed 28 July 2016; The Inspection Panel, Ecuador: Mining Development and Environmental Control Technical Assistance Project (Loan No. 6355-EC), Investigation Report (23 February 2001) paras 101-08 <http://ewebapps.worldbank.org/apps/ip/ PanelCases/20-Investigation Report (English).pdf> accessed 28 July 2016; Cambodia: Forest Concession Management and Control Pilot Project, Investigation Report (n 110) paras 25154; The Inspection Panel, Peru: Lima Urban Transport Project (Loan 7209-PE), Investigation Report (18 January 2011) paras 100-15 <http://ewebapps.worldbank.org/apps/ip/Pages/ ViewCase.aspx?CaseId=79> accessed 28 July 2016.

116 The Inspection Panel, Albania: Power Sector Generation and Restructuring Project (IDA Credit No.3872-ALB), Request for Inspection (30 April 2007) <http://ewebapps.worldbank.org/apps/ ip/PanelCases/46-Request for Inspection (English).pdf> accessed 28 July 2016.

117 ibid; Investigation Report (7 August 2009) paras 310-11 <http://ewebapps.worldbank.org/ apps/ip/PanelCases/46-Investigation Report (English).pdf> accessed 28 July 2016. 
brought to the Aarhus Convention Compliance Committee, and the latter had found breaches of the relevant obligations. ${ }^{118}$

In reaching its conclusions, the Inspection Panel extensively considered the findings of the Aarhus Compliance Committee. It firstly held that, despite the Aarhus Committee focusing on the actions of the Albanian Government rather than those of the Bank, the Committee's conclusions were relevant to the Inspection Panel. This was because Bank policy imposed an obligation on the borrower to hold public consultations and required the Bank to ensure the borrower's implementation of this obligation. Also, the requirements of the Aarhus Convention were similar to those under Bank policy. ${ }^{119}$

The Panel then summarised the Aarhus Committee's investigation and findings. ${ }^{120}$ It then stated that Bank policy required a project's EIA to consider the borrower's international environmental obligations relevant to project activities. It added that the Bank did not finance project activities that would contravene the borrower's international obligations. As Bank Management did not ensure the borrower's fulfilment of its Aarhus obligations, the Panel concluded that the project did not adhere to Bank policy. ${ }^{121}$

In addition to its findings on the borrower's violation of its Aarhus obligations, the Inspection Panel found other breaches in this case. It noted that Bank policy required consultation to take place when preparing the EIA. However, the public meetings concerned were held only after the project site had been decided. ${ }^{122}$ The Panel noted that such consultation only provided post hoc justification for the site selection, which in essence was not a genuine consultation. ${ }^{123}$ As for inadequate notification and public participation, the Panel held that, since there was a similarity between the requirements under Bank policy and the Aarhus Convention, and the Panel had also verified the facts that the Aarhus Committee examined, it reached the same conclusion as the Aarhus Committee: the project did not ensure adequate notification and public participation in consultation meetings during project preparation. ${ }^{124}$

118 ibid para 312.

119 ibid para 323.

120 ibid paras 324-29.

121 ibid paras 330-32.

122 ibid paras 337-41.

123 ibid paras $342-43$.

124 ibid paras $350-52$. 
This is another example where the Inspection Panel referred to the borrower's treaty obligations relevant to project finance activities. The difference between this case and the DR Congo Forest-related Operations case is that here the borrower's Aarhus obligations were raised by the complainants. The Panel in this case found the project to be non-compliant with Bank policy in general terms under OP 4.01, para 3 in light of the Aarhus obligations. It also examined the compatibility of these Aarhus requirements with the public consultation and disclosure requirements under Bank policy, as provided in OP 4.01, paragraphs 14 to 15, and reached the same conclusion as the Aarhus Committee. This shows the importance of civil society, as a complainant, in triggering the Panel's investigation on the borrower's compliance with its treaty obligations when implementing its Bank-funded investment activities. The complainants' reference to the practice under the Aarhus Convention not only had a direct impact on the Panel's findings in this case, it also became an important precedent for considering the requirements under the Aarhus Convention and the Aarhus Committee's decisions in assessing complaints against projects that are implemented by the Aarhus Convention's States Parties in future cases.

\subsection{Natural Habitats ${ }^{125}$}

The Bank's safeguard policies also regulate other environmental issues arising from Bank-financed investment activities. According to Bank policy as revised in 2013, the Bank does not support projects involving significant conversion ${ }^{126}$ or degradation ${ }^{127}$ of critical natural habitats. ${ }^{128}$ Nor does the Bank support projects involving significant conversion of natural habitats, unless there are no feasible alternatives for the project and its siting, and comprehensive analysis shows that the project's overall benefits substantially outweigh its environmental costs. ${ }^{129}$

125 The term 'natural habitats' is defined as 'land and water areas where (i) the ecosystems' biological communities are formed largely by native plant and animal species, and (ii) human activity has not essentially modified the area's primary ecological functions'. The World Bank, Natural Habitat (June 2001) OP 4.04, Annex A, para 1(a) <https://policies.worldbank.org/ sites/ppf3/PPFDocuments/Forms/DispPage.aspx?docid=1568\&ver=current $>$ accessed 28 July 2016.

126 For the meaning of 'significant conversion', see ibid, Annex A, para 1(c).

127 For the meaning of 'degradation', see ibid, Annex A, para 1(d).

128 ibid para 4; For the meaning of 'critical natural habitats', see ibid, Annex A, para 1(b).

129 ibid para 5. 
When an EIA finds that the project would significantly convert or degrade natural habitats, mitigation measures, which may involve minimising habitat loss as well as founding and maintaining an ecologically similar protected area, should be included. $^{130}$

The Pakistan: National Drainage Program (NDP) Project case involved resolving the waterlogging and salinity problems in the Indus Basin's existing irrigation network. The project included extending the Left Bank Outfall Drain (LBOD) system, the central feature of which was a spinal drain. This spinal drain disposed of saline effluent, generated upstream of the Indus Basin, through the Tidal Link to the Arabian Sea. ${ }^{131}$ However, the project underestimated the risk of extreme meteorological events and it lacked appropriate technical measures during the design of the LBOD system and the Tidal Link. ${ }^{132}$ Over time, parts of the structures collapsed. Others suffered damages after being hit by tropical cyclones, ${ }^{133}$ causing suffering to people and significant changes to the regional ecosystem. ${ }^{134}$

The complaint was filed by several individuals on their own behalf and on behalf of those who lived in the project-affected area. The complainants contended, inter alia, that the affected wetlands and interconnected lakes (known as 'dhands') were an important component of international migration routes for many bird species. ${ }^{135}$ In particular, two of the dhands were in the Ramsar Convention List of Wetlands of International Importance, to which the borrowing government was a party. They argued that, according to the Ramsar Convention, the government had to ensure the wise use and conservation of wetlands. Meanwhile, the Bank should not support project activities that would contravene a country's international environmental obligations. $^{136}$

The Inspection Panel found that the chosen route of the major drainage canal-the Tidal Link - ran through the biodiversity-rich and productive dhands. However, because of the structures' failure, the dhands had become part of the Arabian Sea's tidal system. High salinity in the dhands had significantly affected

130 For the meaning of 'Appropriate conservation' and 'mitigation measures', see ibid, Annex A, para $1(\mathrm{e})$.

131 The Inspection Panel, Pakistan: National Drainage Program Project (Credit No. 2999-PAK), Investigation Report (6 July 2006) paras 78-97 <http://ewebapps.worldbank.org/apps/ip/ PanelCases/34-Investigation Report (English).pdf> accessed 28 July 2016.

132 ibid paras 133-53.

133 ibid paras 154-69.

134 ibid paras 170-94.

135 ibid; Request for Inspection (9 September 2004) para $38<$ http://ewebapps.worldbank.org/ apps/ip/PanelCases/34-Request for Inspection (English).pdf> accessed 28 July 2016.

136 ibid para 40. 
the environment. ${ }^{137}$ The Panel held that the project had focused on evacuating effluents and had somewhat neglected the impacts on, or means to rehabilitate, the dhands as a habitat and ecosystem. It concluded that this did not comply with Bank policy. ${ }^{138}$

The Inspection Panel then mentioned the objectives of the Ramsar Convention. It reiterated the States Parties' obligation to designate suitable wetlands within its territory for inclusion in the Ramsar List and to promote the conservation of wetlands in the List. ${ }^{139}$ It stated that the evidence had shown that the dhands under the Ramsar List had suffered negative impacts as a result of rising salinity and changed water flow, which constituted a 'significant conversion or degradation' in terms of Bank policy. ${ }^{140}$

The Inspection Panel held that the Bank had failed to consider the risks of further degrading critical natural habitats adequately, saying that 'these Ramsarlisted sites are the type of critical natural habitat that Bank policy promises not to significantly convert or degrade. ${ }^{141}$ It also ruled that actions were not taken to conserve and rehabilitate these degraded natural habitats. The Panel thus concluded that the project did not adhere to Bank policy. ${ }^{142}$

In this case, the complainants stressed the importance of the wetlands on which the project had had a negative effect by identifying their ecological value and status under the Ramsar Convention, to which the borrower was a State Party. However, the complainants did not explicitly argue that these wetlands constituted 'critical natural habitats' because of their Ramsar status. ${ }^{143}$ This aligns with the Bank policy on natural habitats, which also does not define critical natural habitats as areas listed under the Ramsar Convention or other MEAs. ${ }^{144}$

137 ibid, Investigation Report (n 131) paras 341-45.

138 ibid para 346.

139 ibid paras $347-48$

140 ibid paras 349-54.

141 ibid para 357.

142 ibid paras 366-69.

143 Unlike the WHC, the Ramsar Convention does not have a screening procedure for including a wetland in the List of International Importance. Instead, the States Parties to the Convention can unilaterally designate wetlands to the List. See the Convention on Wetlands of International Importance especially as Waterfowl Habitat (adopted 2 February 1971, entered into force 21 December 1975) 996 UNTS 245 art 2(2) [hereinafter 'Ramsar Convention']; See also Bowman, Davies and Redgwell (n 102) 408-11.

144 The Bank policy on natural habitats only refers to areas which meet the criteria under the IUCN classifications and are considered as critical natural habitats. See OP 4.04, Natural Habitat (n 125) Annex A, para 1(b)(i). 
In contrast to the complainants' submissions, in assigning the wetlands concerned as critical natural habitats under Bank policy, the Inspection Panel appears to have considered the criteria for the inclusion of wetlands in the Ramsar List. ${ }^{145}$ Its holdings were thus beyond what the complainants argued. Therefore, the borrower's commitments under the Ramsar Convention may increase the possibility for a specific area within its territory to be classified as a 'critical natural habitat' under the Bank policy on natural habitats, thereby reinforcing the Bank's duty to refrain from financing project activities that would cause significant conversion or degradation.

In addition, according to the Ramsar Convention, the States Parties have the obligation to promote the conservation and wise use of wetlands, whether they are listed sites or not. ${ }^{146}$ It has been suggested that the focus has been on the States Parties' 'wise use of wetlands. ${ }^{147}$ The term 'wise use' refers to 'the maintenance of their ecological character, achieved through the implementation of ecosystem approaches, within the context of sustainable development. ${ }^{148}$ In this case, since the project had altered the wetlands' ecological character, the borrowing government's obligation for wise use of wetlands under the Ramsar Convention, as mentioned by the complainants, may have been violated. Since the Inspection Panel also indicated that these 'Ramsar-listed sites are the type of critical natural habitat that Bank policy promises not to significantly convert or degrade, ${ }^{149}$ the Panel may consider the practice concerning 'wise use' under the Ramsar Convention in determining compliance with Bank policy in future cases.

\subsection{Forests}

According to the Bank policy on forests, as revised in 2013, the Bank intends to: (i) 'assist borrowers to harness the potential of forests to reduce poverty in a sustainable manner'; (ii) 'integrate forests effectively into sustainable economic development'; and (iii) 'protect the vital local and global environmental services and values of forests. ${ }^{150}$

145 Pakistan: National Drainage Program Project, Investigation Report (n 131) paras 341-42.

146 Ramsar Convention (n 143) arts 3(1), 4(1).

147 Bowman, Davies and Redgwell (n 102) 414-16.

148 ibid 417-19 (emphasis added).

149 Pakistan: National Drainage Program Project, Investigation Report (n 131) para 357.

150 OP 4.36, Forests (n 62) para 1. 
The Bank policy formulations on forests are similar to those for natural habitats in many respects. First, the Bank does not finance projects that would involve significant conversion or degradation of critical forest areas or related critical natural habitats. ${ }^{151}$ Here, 'critical forest areas' refer to forest areas that qualify as 'critical natural habitats' under the Bank policy on natural habitats. ${ }^{152}$ Second, the Bank does not support projects if they would significantly convert or degrade natural forests or related natural habitats, unless there are no feasible alternatives for the project and its siting, and comparative analysis shows that the project's overall benefits substantially outweigh its environmental costs. ${ }^{153}$ Third, the Bank does not support projects that would contravene applicable international environmental agreements. ${ }^{154}$

The Cambodia: Forest Concession Management and Control Pilot Project case best illustrates how the Inspection Panel has dealt with forest issues in a Bankfinanced project in light of international obligations of the borrower. The project involved reforming the regulatory framework for forest concession operations in Cambodia. Its objectives were to improve forest management through effective operational guidelines and to control procedures in forest concessions areas, and to establish forest crime monitoring and prevention capacities. ${ }^{155}$

The complaint was brought by a local-based NGO, ie NGO Forum on Cambodia, on behalf of the affected communities living in the concession areas. The complainants stated that the project's flawed design and implementation promoted the interests of logging companies with track records of human rights abuses and illegal logging. They also asserted that social and environmental impacts were inadequately considered, which had harmed forest-dependent communities and would continue to do so. ${ }^{156}$

Specifically, regarding the alleged breach of the Bank policy on forests, the complainants contended that the project failed to 'ensure conservation, sustainable use of forests and active participation of local people. ${ }^{, 157}$ Neither did it consider

151 ibid para 5.

152 ibid, Annex A, para (c).

153 ibid para 5.

154 ibid para 6.

155 Cambodia: Forest Concession Management and Control Pilot Project, Investigation Report (n 110).

156 ibid; Request for Inspection (28 January 2005) 2 <http://ewebapps.worldbank.org/apps/ip/ PanelCases/36-Request for Inspection (English).pdf> accessed 28 July 2016.

157 Investigation Report (n 110) para 153. 
the social, economic and environmental aspects of the forests being considered for concession. ${ }^{158}$ In particular, forests of high ecological value, especially the Prey Long forest, were consequently not identified as such. They argued that the Bank financed logging in areas of high ecological value and in doing so caused further degradation. ${ }^{159}$ Moreover, extensive illegal logging by concession companies had affected the livelihoods of forest-dependent communities. ${ }^{160}$

In this regard, the Inspection Panel noted that forests of high ecological value should have been identified, especially the Prey Long forest. It found that this forest had been included in a listing of tentative natural sites for World Heritage consideration for Cambodia because of its importance for biodiversity conservation. However, the Prey Long area was covered by three concessions and could be subject to industrial logging. ${ }^{161}$

The Panel considered that the Prey Long forest should be designated a 'forest of high ecological value. ${ }^{, 162}$ It suggested that even though the Bank did not support logging forests of high ecological value, "by not raising the Prey Long issue explicitly, there [was] an implicit acknowledgement that logging in the Prey Long area may be acceptable. ${ }^{163}$ By failing to identify the high ecological value of the forest during the project's early stages, the Panel held that the project did not comply with the Bank policy on forests. ${ }^{164}$

In identifying the Prey Long forest as one of the 'forests of high ecological value' under the Bank policy on forests in this case ${ }^{165}$ the Inspection Panel referred to the forest's status under the tentative list for World Heritage consideration for Cambodia without the complainants doing so. This was despite the fact that natural property on the WHL or on the tentative list was not explicitly stated in Bank policy as a factor in determining the nature of a specific forest area.

According to the WHC, the States Parties shall submit to the World Heritage Committee an inventory of property they consider to be of cultural and natural

158 ibid para 154.

159 ibid para 170.

160 ibid para 226.

161 ibid paras 173-74.

162 ibid xi.

163 ibid paras 176-77.

164 ibid para 180.

165 According to the Bank policy on forests as revised in 1993, 'In forest areas of high ecological value, the Bank finances only preservation and light, non-extractive use of forest resources'. See Shihata (n 16) 392. This provision no longer exists in the 2013 version. 
heritage importance for inscription on the WHL. ${ }^{166}$ Nominations to the WHL will not be considered unless the property has been listed on the party's tentative list. The obligation of the States Parties under the WHC applies to all cultural and natural heritage, regardless of whether they have been inscribed on the WHL. ${ }^{167}$

In assigning the Prey Long forest as a forest of high ecological value and holding that three concessions under the project would cover that forest area and pose a threat to it, the Inspection Panel evidently considered the status of the Prey Long forest under the World Heritage tentative list. While the original stipulation noting 'forests areas of high ecological value' no longer exists in the Bank policy on forests, as the current Bank policy states that ' $\mathrm{t}$ ] he Bank does not finance projects that contravene applicable international environmental agreements'; ${ }^{168}$ natural forest areas that are either on the WHL or tentative lists may still be considered in determining 'critical forest areas'.

\section{Conclusion}

The creation of the Inspection Panel, as an accountability mechanism within the World Bank, is a crucial development in the international legal system. It allows private individuals affected by the Bank's financed projects, which have traditionally been deemed to benefit borrowing countries, to challenge the legitimacy of the Bank's lending decisions. This shows that the interests between the government and its citizens in project finance activities may not be identical. ${ }^{169}$ It also demonstrates the importance of non-economic values, which the World Bank increasingly emphasises, in the pursuit of economic growth through project finance activities.

As an internal accountability mechanism within the World Bank, the Inspection Panel has the mandate to examine whether the Bank's decisions and operations on project finance conform to the Bank's safeguard policies. This is important in securing the rights and interests of those who should be the ultimate beneficiaries of Bank-financed projects. By finding the Bank's non-compliance with its policies and procedures, the Inspection Panel not only enhances the

167 Bowman, Davies and Redgwell (n 102) 454.

168 OP/BP 4.36, Forests (n 62) para 6.

169 James Cameron and Ruth Mackenzie, 'Access to Environmental Justice and Procedural Rights in International Institutions' in Michael Anderson and Alan Boyle (eds), Human Rights Approaches to Environmental Protection (Clarendon Press 1998) 147-49. 
accountability of the lending institution to the public, but also performs a significant role in interpreting the applicable social and environmental norms in the context of project finance.

Although the Inspection Panel is not a judicial mechanism, certain institutional arrangements ensure its independence from the organisation that founded it when conducting investigations. This reflects the Panel's ombudsman feature and helps to strengthen its effectiveness in addressing private complaints brought against the Bank. ${ }^{170}$ Moreover, while it is not the Inspection Panel's primary mandate to examine the borrower's fulfilment of its treaty obligations pertaining to project activities, this does not preclude the Panel from using international law, including MEAs, to determine whether Bank policies have been implemented. ${ }^{171}$ As previously noted, the World Bank's operational policies and procedures address different environmental issues, including EIAs, natural habitats and forests. In practice, these rules have become important bases for the Panel to examine the borrowing governments' fulfilment of their treaty obligations relevant to project activities under specific MEAs.

On some occasions, the Inspection Panel has examined the projects' compliance with Bank rules in light of the borrowers' MEA obligations on the basis of the relevant Bank policies' explicit references to international environmental treaties and agreements. ${ }^{172}$ On other occasions, the Panel has identified and considered the borrowers' environmental treaty obligations without any particular references to such MEAs in Bank policies. ${ }^{173}$ Save for the Aarhus Convention, ${ }^{174}$ the MEAs referred to in these cases (ie CITES, WHC and the Ramsar Convention) have

170 See generally, Ole Kristian Fauchald, 'Hardening the Legal Softness of the World Bank through an Inspection Panel?' (2013) 58 Scandinavian Studies in Law 101.

171 Alix Gowlland Gualtieri, 'The Environmental Accountability of the World Bank to Non-State Actors: Insights from the Inspection Panel' (2001) 72 British YB Intl L 213, 245-46.

172 See, eg, DR Congo Forest-Related Operations, Investigation Report (n 91) paras 388-94 (referring to the CITES and WHC); Albania: Power Sector Generation and Restructuring Project, Investigation Report (n 116) paras 323-32, 337-43, 347-52 (referring to the Aarhus Convention).

173 See, eg, Pakistan: National Drainage Program Project, Investigation Report (n 131) paras 34754, 357 (referring to the Ramsar Convention); Cambodia: Forest Concession Management and Control Pilot Project, Investigation Report (n 110) (referring to the WHC).

174 As of 20 May 2016, there are 47 parties to the Aarhus Convention. UNECE (Status of Ratification) <http://www.unece.org/env/pp/ratification.html> accessed 28 July 2016. 
generally been ratified by the majority of states. ${ }^{175}$ Also, the borrowing governments concerned in the abovementioned cases were the States Parties to these MEAs. On the one hand, this shows the Panel's willingness to consider those widely accepted MEAs in its investigations, even if such MEAs are not referred to in Bank policies. This also means that both the World Bank and the governments have to be aware of, and comply with, these environmental treaty obligations (especially those that have been ratified by the borrowing governments) in the course of project finance activities. On the other hand, it remains to be seen whether the Panel will examine the project's compliance with Bank policies in light of specific MEAs to which the borrowing governments concerned are not state parties. ${ }^{176}$

Moreover, through these Bank policies, civil society organisations can seek to assert their influence on the behaviour of both the World Bank and the borrowing governments in conducting project activities. In practice, civil society organisations have contributed to this by identifying the borrower's international environmental commitments in their complaints. ${ }^{177}$ This shows the importance of civil society's arguments in promoting the implementation of MEA obligations

175 As of 2016, there are 182, 192 and 169 parties to CITES, WHC and the Ramsar Convention respectively. CITES (Member countries) <https://cites.org/eng/disc/parties/index.php > accessed 28 July 2016; UNESCO (States Parties/Ratification status) <http://whc.unesco.org/ en/statesparties/> accessed 28 July 2016; The Ramsar Convention Secretariat (Contracting Parties to the Ramsar Convention) <http://www.ramsar.org/sites/default/files/documents/ library/annotated_contracting_parties_list_e.pdf> accessed 28 July 2016.

176 The Performance Standards on Environmental and Social Sustainability of the International Finance Corporation (IFC) and the Multilateral Investment Guarantee Agency (MIGA) have provided the possibility for the IFC/MIGA Compliance Advisor Ombudsman (CAO) to evaluate the project's compliance with the Performance Standards in light of MEAs to which the home states of private sector clients are not state parties. For example, according to IFC/ MIGA Performance Standard 3 (PS3), the transboundary pollutants that the client should avoid, minimise and/or control releasing include those identified in the Convention on LongRange Transboundary Air Pollution (adopted 13 November 1979; entered into force 11 June 1981) 1302 UNTS 217 (LRTAP). As the majority of the state parties to LRTAP are based in Europe and North America, but IFC/MIGA-supported projects are implemented in developing countries around the world, the reference to LRTAP under PS3 implies the practical effect of this Convention extending beyond the state parties to private sector companies of noncontracting parties. This also allows the CAO to evaluate the project's compliance with the applicable standards in light of an MEA to which neither the IFC/MIGA nor the home state of the private sector client is a party.

177 See, eg, Albania: Power Sector Generation and Restructuring Project, Investigation Report (n 116) para 312 (referring to the Aarhus Convention); Pakistan: National Drainage Program Project, Request for Inspection (n 131) para 40 (referring to the Ramsar Convention). 
in project finance activities. As the Inspection Panel is a rule-based dispute settlement mechanism, in order to prompt the Panel actively to take account of MEA obligations when conducting investigations, it is of paramount importance to ensure that complainants advance their arguments according to pertinent Bank policies, which may well involve MEAs in an effective manner. The organisations' sharing of information and experience and assistance for local communities and NGOs, especially those in developing countries, can help to build and strengthen the capacity of civil society to make complaints.

As Ellen Hey has noted, although the Inspection Panel does not base its findings on international law in a strict sense, this does not prevent it from considering the project's compliance with treaty obligations pertinent to project finance activities. ${ }^{178}$ The Panel's proactive attitude in tackling environmental issues in light of the borrowing government's MEA obligations promotes and contributes to the fulfilment of these treaty requirements by governments and the World Bank when designing, appraising and implementing project activities. Meanwhile, this also allows civil society to influence both the borrowers and the lending institution in implementing project finance activities through Bank policies, which, from a legal perspective, are soft-law instruments.

Finally, it is worth noting that the Inspection Panel adopted its pilot approach in 2014 in order to reach early solutions through dialogue without formal investigations. ${ }^{179}$ This early problem-solving approach was launched for the first time in Nigeria: Lagos Metropolitan Development and Governance Project, which concerned the compensation issue arising from the demolition of hundreds of homes as part of a housing development project. ${ }^{180}$ Future research should investigate if and how the pilot approach will be applied to environmental issues and the role of MEAs, which would otherwise be considered if private complaints are resolved through formal investigations, in the pilot approach.

Meanwhile, the World Bank is now reviewing and updating its current safeguard policies. The second draft of the Environmental and Social Framework

178 Ellen Hey, 'The World Bank Inspection Panel and the Development of International Law' in Nerina Boschiero, Tullio Scovazzi, Chiara Ragni and Cesare Pitea (eds), International Courts and the Development of International Law: Essay in Honour of Tullio Treves (Springer 2013) 731.

179 See text to $n 27-46$.

180 The Inspection Panel, Nigeria: Lagos Metropolitan Development and Governance Project, Notice of Non-Registration and Panel's Observations of the First Pilot to Support Early Solutions (16 July 2014) <http://ewebapps.worldbank.org/apps/ip/PanelCases/91-Notice of Non-Registration (English).pdf $>$ accessed 28 July 2016. 
was issued on 1 July 2015. The proposed Framework comprises a Version for Sustainable Development, the World Bank Environmental and Social Policy for Investment Project Financing, and the Environmental and Social Standards (ESS). ${ }^{181}$ This Framework is meant to replace several current OPs and BPs, including OP/BP 4.01 on EIA, OP/BP 4.04 on Natural habitats and OP/BP 4.36 on Forests. ${ }^{182}$ The draft ESS has in many respects emphasised the importance of the borrower to fulfil its international environmental obligations. ${ }^{183}$ However, the relevant rules do not further specify any particular MEAs that should be adhered to by the borrower. It remains to be seen whether specific MEAs will eventually be incorporated into the ESS and how these rules are applied and interpreted by the Inspection Panel following the adoption of the Environmental and Social Framework.

The establishment of the World Bank Inspection Panel is a constructive step in holding MDBs accountable for their activities. The operation of the Inspection Panel may not only provide redress for those affected by project finance decisions and operations, but also facilitate the implementation of social and environmental rules set out by the World Bank. Based on the above case analysis, this article concludes that the Inspection Panel has actively considered environmental issues in light of MEAs, along with other concerned operational policies and procedures of the World Bank. This was despite the fact that these Bank rules refer to MEAs only on a few occasions. The World Bank Inspection Panel represents an important

181 The World Bank, 'Environmental and Social Framework: Setting Environmental and Social Standards for Investment Project Financing, Second Draft for Consultation' (1 July 2015), para $2<$ https://consultations.worldbank.org/Data/hub/files/consultation-template/reviewand-update-world-bank-safeguard-policies/en/materials/clean_second_draft_es_framework_ final_draft_for_consultation_july_1_2015.pdf> accessed 28 July 2016.

182 ibid para 12.

183 See, eg, The World Bank, 'Environmental and Social Standard 1. Assessment and Management of Environmental and Social Risks and Impacts', para $24<$ https://consultations.worldbank.org/ Data/hub/files/consultation-template/review-and-update-world-bank-safeguard-policies/en/ materials/second_draft_proposed_environmental_and_social_standard_ss1.pdf > accessed 28 July 2016; The World Bank, 'Environmental and Social Standard 3. Resource Efficiency and Pollution Prevention and Management', paras 18, 19, $22<\mathrm{https://consultations.worldbank.}$ $\mathrm{org} / \mathrm{Data} / \mathrm{hub} /$ files/consultation-template/review-and-update-world-bank-safeguardpolicies/en/materials/second_draft_proposed_environmental_and_social_standard_ss3.pdf> accessed 28 July 2016; The World Bank, 'Environmental and Social Standard 6. Biodiversity Conservation and Sustainable Management of Living Natural Resources', para 24 (b) <https:// consultations.worldbank.org/Data/hub/files/consultation-template/review-and-updateworld-bank-safeguard-policies/en/materials/second_draft_proposed_environmental_and_ social_standard_ss6.pdf > accessed 28 July 2016. 
example in modern international law in that, as an accountability mechanism, it has taken on a positive role of ensuring the projects' compliance with the environmental treaty obligations of the borrowing countries. Other similar mechanisms set up in regional $\mathrm{MDBs}^{184}$ should learn from the experience of the Inspection Panel when exercising their investigatory mandates.

184 See, eg, the Independent Consultation and Investigation Mechanism in the Inter-American Development Bank, the Accountability Mechanism in the Asian Development Bank, the Project Complaint Mechanism in the European Bank for Reconstruction and Development, and the Independent Review Mechanism in the African Development Bank. 